\title{
Heavy metal and Bacteriological analysis in spring water of North Sikkim with reference to seasonal variation
}

\author{
Asha Subba ${ }^{1}$, M. Pandey ${ }^{2}$, Sangeeta $\mathrm{Jha}^{3}$ and Karma Gurmey Dolma ${ }^{4}$ \\ ${ }^{1}$ Research scholar, Department of Chemistry, SMIT, Majitar, Sikkim, India \\ 2,3 Department of Chemistry, SMIT, Majitar, Sikkim, India \\ ${ }^{4}$ Department of Microbiology, SMIMS, Tadong, Sikkim, India
}

\begin{abstract}
Background/Objectives: The natural spring (dhara) is the main source of drinking water in North Sikkim. Though it is pure water for drinking and other domestic purposes, it gets polluted with various environmental factors. Methods/Statistical analysis: The study was performed to assess the quality of spring water. A total of nine sampling sites were selected at an interval of four months, i.e. monsoon, pre-monsoon and post-monsoon during August 2015-July2016. Findings: All the spring water samples were analyzed in terms of physical properties, heavy metals like copper, lead, iron, chromium, cadmium and bacterial characteristics such as Escherichia coli, Klebsiella sp, Salmonella sp, Shigella sp, Proteus sp, Citrobacter sp, Enterobacterclocae etc. In the study all the observed results were compared with Bureau of Indian Standard. Improvements/Applications: All the results of physical parameters and heavy metals were found within the permissible limit except the range of $\mathrm{pH}$ and iron shows slightly higher concentration than permissible limit. During monsoon, isolation of organisms was recorded in significant percentage followed by post-monsoon and pre-monsoon.
\end{abstract}

\section{Index Terms}

Bacteria, Physico-Chemical Parameters, Spring Water, Seasons

\footnotetext{
Corresponding author : Asha Subba

ashasubba630@yahoo.com

- Manuscript received June 3, 2018.

- Revised July 22, 2018 ; Accepted August 7, 2018.

- Date of publication September 30, 2018.

(C) The Academic Society of Convergence Science Inc.

2546-1583 @ 2017 IJEMR. Personal use is permitted, but republication/redistribution requires IJEMR permission.
} 


\section{INTRODUCTION}

Sikkim is the $22^{\text {nd }}$ state of India and very small hilly state in the eastern Himalayas, extending approximately $114 \mathrm{kms}$ from north to south and 64 $\mathrm{kms}$ from east to west. The state being a part of inner ranges of the mountain of Himalaya and its elevation is ranging from 300 to $8583 \mathrm{mtrs}$ [1].

The total population of Sikkim is $6,07,688$ as per 2011 census. North Sikkim is the largest (4,226 sq. $\mathrm{km}$.) in area but in term of population it is the smallest with $(43,709)$ out of this, the rural population is $39065(89.37 \%)$ and the urban population is $4644(10.62 \%)$ [2]. Maximum number of the population resides in rural areas than urban who fulfill their basic needs with the spring water sources (untreated) as their main source of drinking, irrigation and other domestic purposes. Springs occur where inclined ground and impermeable strata intersect with ground water table [3]. In Sikkim, weather condition also plays a vital role in the amount of water flow during the months from early May to October. Spring (dhara) water said to be pure and natural water, however it contain various minerals, salts and micro-organism which comes from rain water, sediment soil through landslides, soil erosion and anthropogenic activities. Since, the water is in continuous contact with the surface and thereby increasing the risk of microbial presence and elemental contamination from country rocks[4].Contamination of water in rural areas can cause by different factors like runoff water, poor sanitations, human and animal excreta and waste etc. The water that comes from the rainfall and the mountains results in small streams, springs and kholas [5] which are further tapped into pipelines and distributed with or without any treatment for drinking and domestic purpose. In the rural areas people depend on untreated water sources due to lack of awareness about the quality and contamination of water which needs at least basic treatment before consumption. Testing of water quality on a regular basis is, therefore an important part of maintaining a safe and reliable source [6]. Water pollution results in transmission of infectious diseases such as dysentery, cholera, diarrhea, typhoid, shigellosis, salmonellosis and varieties of other bacteria as well as fungi, viral and parasitic infection [7]. Reliable information on the qualities of raw water is necessary to guide its suitability for use [8]. Therefore, the present study intend to assess the quality of spring water used for drinking, irrigation and domestic purposes in rural areas of North Sikkim by determining the physico-chemical parameters and bacterial characteristics, as the quality of water plays a crucial role for preventing diseases and enlightening better quality of life for the population, animals and irrigation purposes.

\section{Materials And Methods}

The study was conducted in rural areas of North Sikkim, during the period from August 2015 - July 2016. A total of twenty seven spring water samples, nine samples from each site were collected at an interval of four months that is, monsoon, postmonsoon and pre-monsoon. A liter of spring water sample for physico-chemical and $500 \mathrm{ml}$ for bacterial analysis were collected in air tight container from the selected sources. Sample bottle was labeled with full details of the selected source at the time of sample collection. The value of $\mathrm{pH}$ and temperature were measured at the sampling site using a pocket-sized pH meter (Hanna Instrument) and mercury thermometer. The collected samples for bacterial analysis were transported to the laboratory using ice box. The physical parameters were measured in the laboratory within 24 hours of sample collection using conductivity meter, nephelometric method, azide modification method, titrimetry method and heavy metals were determined within six months of sample collection using concentrated $\mathrm{HNO}_{3}$ as preservative and analysed with the help of inductively coupled plasma mass spectrometry (ICPMS) as per the standard guidelines of the American Public Health Association (APHA) [9]. For bacteriological analysis, the water samples were analysed within 6 hours of collection using membrane filtration method. The membrane apparatus were autoclaved for sterilization at $115^{\circ} \mathrm{C}$ for 10 minutes and $250 \mathrm{ml}$ of each sample was filtered through a cellulose acetate grided membrane filter (47 mm diameter, $0.45 \mu \mathrm{m}$ pore size, Millipore) with the help of vaccum. The filtered membrane was transferred on MacConkey agar plate (Himedia, Mumbai) and the plate was incubated at $37^{\circ} \mathrm{C}$ overnight. Further identification of the organism in collected water samples was performed on the basis of biochemical characteristics, conventional method of morphological and cultural characteristics of the isolated colony using standard guidelines of Mackie and McCartney [10].

\section{Result AND Discussion}

The study has been conducted in different areas of North Sikkim on the basis of seasonal variation. The analysis for the quality of different spring water has been carried out which includes physical parameters, heavy metals and bacterial characteristics are shown in the tables 1,2 and 3.The average temperatures were measured with a minimum range of $11^{\circ} \mathrm{C}$ during post-monsoon with a mean of $17.3^{\circ} \mathrm{C}$ to maximum range of $25{ }^{\circ} \mathrm{C}$ during monsoon with a mean $22^{\circ} \mathrm{C}$. The variation in temperature may be due 
to various factors such as climate of geographical area, extend of shade from direct sunlight and depth of water and high population rates[11], $\mathrm{pH}$ were measured with a minimum range of 6 during monsoon with a mean 6.9 to maximum range of 8.86 during pre- monsoon with a mean 8 . The $\mathrm{pH}$ value showed slightly alkaline during pre-monsoon due to the presence of carbonates and bicarbonates [6]. Similarly, the $\mathrm{pH}$ value of fresh spring water of Kashmir Himalaya also showed in alkaline range [12]. The alkaline range may be due to mixing up of the alkaline chemicals, soap and detergents etc. produce due to industrial, commercial and residential activities. The ISI permissible $\mathrm{pH}$ values containing water is suitable for domestic use and irrigation purposes [13]. Total dissolved solids (TDS) were measured with a minimum range of $10.57 \mathrm{mg} / \mathrm{l}$ during pre-monsoon with a mean $21.82 \mathrm{mg} / \mathrm{l}$ to maximum range of $69 \mathrm{mg} / \mathrm{l}$ during monsoon with a mean $58.3 \mathrm{mg} / \mathrm{l}$. All the studied sample showed the TDS values within the permissible limit which can be considered for drinking [14,15]. High value of TDS in water sample signify high quantity of dissolved solids and less values be a sign of less pollution in water. Conductivity was measured with a minimum range of $23.51 \mu$ s during pre-monsoon with a mean of $44.52 \mu$ s to a maximum range of $94.75 \mu$ s during post-monsoon with a mean $54.8 \mu$ s. In our study conductivity value shows fluctuations may be due to the contamination from domestic sewage and inorganic fertilizer inputs [16], it may be due to bicarbonate and calcium ions present in the rocks [12], turbidity were measured with a minimum range of $0.01 \mathrm{NTU}$ during post-monsoon with a mean $0.13 \mathrm{NTU}$ to a maximum range of $1.28 \mathrm{NTU}$ during monsoon with a mean 0.85 NTU. Turbidity values in all the selected sites were found within the permissible limit of Bureau of Indian Standard [17]. However, most of the water sample was observed high turbid during monsoon due heavy rain, agricultural runoff and soil erosion around studied areas. It might be due to human activities, decrease in the water level and presence of suspended particulate matter [18]. Turbidity can interfere with disinfection and provide a medium for microbial growth [19]. These organisms include bacteria, viruses and parasites that can cause symptoms such as nausea, cramps, diarrhea and associated headaches [20]. Salinity were measured with a minimum range of $24.63 \mathrm{mg} / \mathrm{l}$ during pre-monsoon with a mean $42.53 \mathrm{mg} / \mathrm{l}$ to maximum range of $86 \mathrm{mg} / \mathrm{l}$ during monsoon with a mean $60.9 \mathrm{mg} / \mathrm{l}$. The range of salinity in all the water sample were found within the limit. The reason for the high amount of salinity might be the dissolution of organic waste due to discharge of industrial effluents containing high concentration of chlorides [13]. Presence of dissolved oxygen (DO) is a significant sign of water contamination. In our study dissolved oxygen were measured with a minimum range of $1.2 \mathrm{mg} / 1$ during pre-monsoon with a mean $1.69 \mathrm{mg} / \mathrm{l}$ to maximum range of $3.2 \mathrm{mg} / 1$ during post-monsoon with a mean $2.23 \mathrm{mg} / \mathrm{l}$. All the observed ranges were within the limit. In compare to our study, several authors also observed high range of dissolved oxygen in winter and summer $[21,22]$. Hardness were measured with a minimum range of $28 \mathrm{mg} / 1$ during post-monsoon with a mean $49.4 \mathrm{mg} / \mathrm{l}$ to maximum range of 240 $\mathrm{mg} / \mathrm{l}$ during monsoon with a mean $128 \mathrm{mg} / \mathrm{l}$. Hardness in water of all the selected areas were found within the permissible limit. The highest range of hardness was observed in monsoon. In the present study, the higher concentration of copper $(\mathrm{Cu})(0.179$ $\mathrm{mg} / \mathrm{l})$ and cadmium (Cd) $(0.005 \mathrm{mg} / \mathrm{l})$ were determined which is within the permissible limit and the concentration of lead $(\mathrm{Pb})$ and chromium $(\mathrm{Cr})$ in water samples was found below detection limit in all the three season. However, the concentration of iron (Fe) were determined with a range of $0.126 \mathrm{mg} / 1$ $10.997 \mathrm{mg} / \mathrm{l}$, exceeds the permissible limit of Bureau of Indian Standard [17]. The high concentration of iron was observed during pre-monsoon followed by monsoon and post monsoon. The higher concentration may be due to the anthropogenic activities, sedimentary rocks etc. around the study sites. Higher concentration of iron in water sample may be due to the nature of the metal that is strongly absorbed to soil and more easily dissolved in minutely negligible amounts [24]. Similarly, several authors also observed nearly same concentration of heavy metals in their studies [25,26]. The bacteriological analysis of water plays a vital role as it helps to determine potability of water for drinking and other domestic purposes. In the study highest percentage of bacteria were isolated in monsoon (43.9\%) followed by post-monsoon $(29.2 \%)$ and premonsoon $(26.8 \%)$. Isolation of organisms such as Escherichia coli and Klebsiella $s p$ was in significant number as compared to other organisms like citrobacter $s p$, Salmonella sp, Shigella $s p$, Proteus $s p$ etc. These pathogenic microorganisms lead to the public health significance, such as gastrointestinal infections, diarrohea, dysentery, typhoid and other infections [17].Contamination with various bacteria in water may be due to the presence of bushes and shrubs around the water bodies, rapid growth of population, poor sanitation and lack of cleanliness around the spring bodies [24]. 
International Journal of Emerging Multidisciplinary Research 2018 Sep ; 2(3):1-6

TABLE 1. COMPARATIVE ANALYSIS OF PHYSICAL PARAMETERS

\begin{tabular}{|c|c|c|c|c|c|c|c|c|c|c|}
\hline \multirow[t]{2}{*}{ Parameter } & \multirow[t]{2}{*}{ Unit } & \multicolumn{3}{|c|}{ Monsoon } & \multicolumn{3}{|c|}{ Post-monsoon } & \multicolumn{3}{|c|}{ Pre-monsoon } \\
\hline & & Min & Max & Mean & Min & Max & Mean & Min & $\operatorname{Max}$ & Mean \\
\hline Temperature & ${ }^{\circ} \mathrm{C}$ & 20 & 25 & 22 & 11 & 21 & 17.3 & 13 & 22 & 18.2 \\
\hline $\mathrm{pH}$ & - & 6 & 7.7 & 6.9 & 7.24 & 7.42 & 7.32 & 7.75 & 8.86 & 8 \\
\hline TDS & $\mathrm{mg} / \mathrm{l}$ & 48 & 69 & 58.3 & 17.8 & 42.7 & 26.5 & 10.57 & 37.47 & 21.82 \\
\hline Conductivity & $\mu \mathrm{s}$ & 32 & 60 & 41.3 & 39.62 & 94.75 & 54.8 & 23.51 & 78.53 & 44.52 \\
\hline Turbidity & NTU & 0.23 & 1.28 & 0.85 & 0.01 & 0.22 & 0.13 & 0.46 & 0.92 & 0.70 \\
\hline Salinity & $\mathrm{mg} / 1$ & 42 & 86 & 60.9 & 36.63 & 77.68 & 50.81 & 24.63 & 67.89 & 42.53 \\
\hline Dissolved Oxygen & $\mathrm{mg} / 1$ & 1.68 & 2.32 & 1.96 & 1.6 & 3.2 & 2.23 & 1.2 & 2.24 & 1.69 \\
\hline Hardness & $\mathrm{mg} / 1$ & 76 & 240 & 128 & 28 & 76 & 49.4 & 36 & 80 & 60.5 \\
\hline
\end{tabular}

All the collected samples were analysed during monsoon, post- monsoon and pre- monsoon at an interval of four months and the obtained results shows seasonal variation. Values were expressed in $\mathrm{mg} / \mathrm{l}=$ milligram per liter, $\mathrm{NTU}=\mathrm{Nephelometric}$ Turbidity Unit, $\mu \mathrm{s}=$ microsiemens and ${ }^{\circ} \mathrm{C}=$ degree centigrade.

TABLE 2. COMPARATIVE ANALYSIS OF HEAVY METAL IN WATER SAMPLE.

\begin{tabular}{|l|l|l|l|l|l|l|l|}
\hline \multirow{2}{*}{ Parameter } & \multirow{2}{*}{ Unit } & \multicolumn{2}{c|}{ Monsoon } & \multicolumn{2}{c|}{ Post-monsoon } & \multicolumn{2}{c|}{ Pre-monsoon } \\
\cline { 3 - 8 } & & \multicolumn{1}{c|}{ Min } & \multicolumn{1}{c|}{ Max } & \multicolumn{1}{c|}{ Min } & \multicolumn{1}{c|}{ Max } & \multicolumn{1}{c|}{ Min } & Max \\
\hline Copper & $\mathrm{mg} / 1$ & BDL* & 0.072 & BDL & 0.058 & BDL & 0.179 \\
\hline Lead & $\mathrm{mg} / 1$ & BDL & BDL & BDL & BDL & BDL & BDL \\
\hline Iron & $\mathrm{mg} / 1$ & 0.324 & 8.509 & 0.126 & 3.225 & 0.596 & 10.997 \\
\hline Chromium & $\mathrm{mg} / 1$ & BDL & BDL & BDL & BDL & BDL & BDL \\
\hline Cadmium & $\mathrm{mg} / 1$ & BDL & 0.003 & BDL & 0.003 & BDL & 0.005 \\
\hline
\end{tabular}

*BDL: Below Detection Limit.Heavy metal in water sample were analysed for three season and all the observed values expressed in mg/l= milligram per liter.

TABLE 3. TOTAL PERCENTAGE OF BACTERIAL ORGANISMS ISOLATED IN SELECTED SPRING WATER.

\begin{tabular}{|c|c|c|c|}
\hline ORGANISM & Monsoon & Post-monsoon & Pre-monsoon \\
\hline E.coli & $9(25 \%)$ & $7(29.1 \%)$ & $3(13.6 \%)$ \\
\hline Klebsiella aerogenes & $0 \%$ & $0 \%$ & $0 \%$ \\
\hline Klebsiella pneumonia & $4(11.2 \%)$ & $3(12.5 \%)$ & $3(13.6 \%)$ \\
\hline Klebsiella oxytoca & $2(5.6 \%)$ & $2(8.3 \%)$ & $1(4.5 \%)$ \\
\hline Klebsiella ozania & $3(8.4 \%)$ & $2(8.3 \%)$ & $2(9 \%)$ \\
\hline Klebsiella ornitholytica & $0 \%$ & $0 \%$ & $0 \%$ \\
\hline Klebsiella planticola & $0 \%$ & $0 \%$ & $0 \%$ \\
\hline Shigella dysenteria & $0 \%$ & $1(4.1 \%)$ & $0 \%$ \\
\hline Shigella flexneri & $0 \%$ & $0 \%$ & $0 \%$ \\
\hline Shigella boydii & $0 \%$ & $2(8.3 \%)$ & $1(4.5 \%)$ \\
\hline Salmonella typhi & $0 \%$ & $1(4.1 \%)$ & $0 \%$ \\
\hline Salmonella paratyphi A & $0 \%$ & $1(4.1 \%)$ & $0 \%$ \\
\hline Proteus vulgaris & $0 \%$ & $0 \%$ & $0 \%$ \\
\hline Proteus mirrabilis & $2(5.6 \%)$ & $1(4.1 \%)$ & $0 \%$ \\
\hline Citrobacter freundii & $0 \%$ & $0 \%$ & $0 \%$ \\
\hline Citrobacter koseri & $0 \%$ & $1(4.1 \%)$ & $1(4.5 \%)$ \\
\hline Hafnia alevi & $0 \%$ & $0 \%$ & $1(4.5 \%)$ \\
\hline Morganella morganii & $2(5.6 \%)$ & $0 \%$ & $1(4.5 \%)$ \\
\hline Providencia rettgeri & $2(5.6 \%)$ & $0 \%$ & $0 \%$ \\
\hline Providencia stuartii & $1(2.8 \%)$ & $1(4.1 \%)$ & $0 \%$ \\
\hline Serratia marcescens & $3(8.4 \%)$ & $0 \%$ & $0 \%$ \\
\hline
\end{tabular}




\begin{tabular}{|l|c|c|c|}
\hline Pseudomonas oleovorans & $1(2.8 \%)$ & $0 \%$ & $0 \%$ \\
\hline Pseudomonas alcaligenes & $2(5.6 \%)$ & $0 \%$ & $0 \%$ \\
\hline Pseudomonas aeruginosa & $0 \%$ & $1(4.1 \%)$ & $0 \%$ \\
\hline Pseudomonas putida & $2(5.6 \%)$ & $0 \%$ & $1(4.5 \%)$ \\
\hline Enterobacter cloacae & $1(2.8 \%)$ & $1(4.1 \%)$ & $0 \%$ \\
\hline Alcaligenes faecalis & $2(5.6 \%)$ & $0 \%$ & $2(9 \%)$ \\
\hline Acinetobacterlwoffii & $0 \%$ & $0 \%$ & $1(4.5 \%)$ \\
\hline Acinetobacter baumannii & $0 \%$ & $0 \%$ & $3(13.6 \%)$ \\
\hline Aeromonas hrdrophilla & $0 \%$ & $0 \%$ & $1(4.5 \%)$ \\
\hline Eschericha hermanii & $0 \%$ & $0 \%$ & $1(4.5 \%)$ \\
\hline Moraxella group & $0 \%$ & $24(29.2 \%)$ & $22(26.8 \%)$ \\
\hline Total & $36(43.9 \%)$ & $0 \%$ & \\
\hline
\end{tabular}

Isolation of bacterial organisms in selected spring water during monsoon, post-monsoon and pre-monsoon.

\section{CONCLUSION}

The present study showed that the physical parameters and heavy metals in spring water of selected areas were found within the permissible limit except the value of $\mathrm{pH}$ and iron $(\mathrm{Fe})$ in few areas exceeds the permissible limit. However, water of all the selected areas in North Sikkim were found to be highly contaminated with various pathogenic bacteria which can cause serious health problem. Presence of heavy metal and bacteria in drinking water make serious threat to human health if exposing to long term. Thus, personal hygiene, proper disposal of human and animal waste and maintenance is essential to these water bodies to maintain a quality of water and the treatment or boiling of water is very essential before consumption and other domestic purposes to lead better quality of life.

\section{ACKNOWLEDGMENT}

The authors would like to thank the staff of Sikkim Manipal Institute of Technology (SMIT) Department of Chemistry, Department of Microbiology, Sikkim Manipal Institute of Medical Sciences (SMIMS), and State Pollution Control Board of Sikkim for their support.

\section{REFERENCES}

[1] Geographical information of Sikkim.

[2] Office of the registar general census commissioner (2011) census of India 2011, series I, India, paper 2 of 2011,provisional population totals, Registar general and census commissioner, New Delhi.
[3] Tripathi, D.K. (2015). Physicochemical Analysis of Selected Springs Water Samples of Dehradun City, Uttarakhand, India. Int. J. for innovative research in science and technology. 2(05):99-103.

[4] Ramteke, P.W. (1992). Evaluation of coliforms as indicators of water quality in India.72(4):352-6.

[5] Starkel, L. (1970): Cause and effects of a heavy rainfall in Darjeeling and in the Sikkim Himalayas. J. Bombay Nat. Hist. Soc. 67, 45-50.

[6] Kumar, R.R \& Parita, K. (2014). Physic-chemical and microbial analysis of drinking water in Rajkot district, Gujarat (India). IJES, 5 (2), 0976-4402.

[7] Beniston, M. (2003). Climate change in mountain regions: a review of possible impacts. Climate Change

[8] Nwachu, E. (2013). Bacteriological and physicochemical qualities of drinking water sources in local area of Eastern Nigeria. J. Env. Sc. And water Res 2(9): 336-341.

[9] APHA (2005): Standard methods for examination of water and waste water, 20th edition, American Public Health Association, Washington D.C.

[10] Collee, J.G. (1996). Mackie and McCartney Practical Medical Microbiology. 14th ed. London: Churchill Livingstone. 889-92.

[11] Ekhaise, F.O. (2005). Influence of brewery effluent discharge on the microbiological and physicochemical quality of Ikpobariver, Nigeria. Afri. J.Biotechno 4,1062-1065.

[12] Sheikh, M.A. (2013). A study of physico-chemical characteristics of three fresh water springs of Kashmir Himalaya. India. Int. J. of Water Resources and Environmental Engineering. 5(6):328-331.

[13] Krishnan, R.R., Dharmaraj, K., Kumari, B.D.R (2007). Acomparative study on the physicochemical and bacterial analysis of drinking, borewell and sewage water in the three different places of Sivakasi. J. of Env. Biology, 28 (1), 105-108.

[14] EPA (2003), US: Environmental Protection Agency, Safe Drinking Water Act, EPA 816-F-03-016

[15] WHO (2006). Guidelines for Drinking Water Quality. First Addendum to 3rd Edition, vol. 1. Geneva. 
[16] Kumar, P.B.A.N. (1996).Phytoextraction: The use of plants to remove heavy metals from soils. Environ. Sci. Technol. 29(5):1232-1238.

[17] Drinking water specifications: (2005)10500 Indian standard (IS), 10500 Bureau of Indian standard (BIS).

[18] Yashoda, T., Byragi, B.T., Ramana, C.V (2014).Pre and postmonsoon variation in physico-chemical characteristics in ground water quality of Mindi industrial area, Visakhapatnam, India. IJES,4(5),0976-4402.

[19] National Primary Drinking Water Regulations (NPDWR) and Massachusetts Drinking Water Regulations,(2002), Standard Health Effects Language for Public Notification, Department of Environmental Protection.

[20] US EPA (2003), Water: Basic Information about Regulated Drinking Water Contaminants.

[21] Poonia, S. (2014). Antibiotic susceptibility profile of bacteria isolated from natural sources of water from rural areas of East Sikkim, Indian J. com. Med.39(3):156-160.

[22] Manjare, S.A.,Vhanalakar S.A., Muley,D.V. (2010). Analysis of water quality ushing physico-chemical parameters, Tamdalge tank in Kholapur district, Maharashtra. Int.J. Adv.Biotec. Res.1,115-9.

[23] Parashar, C., Dixit, S., \& Srivastava, R. (2006), Seasonal Variations in Physicochemical characteristics in upper lake of Bhopal, Asian Journal of Experimental Science, 20(2), pp 297-302

[24] Sunday, O.E. (2012). Physicochemical andMicrobiological analysis of water bodies in uturu, Abia state- Nigeria, As. J. of natural and app. Sciences. 1(4): 58-65.ISSN: 22186-8476.

[25] Jeelani, G. (2010). Chemical and microbial contamination of Anantnag springs, Kashmir valley. J.HimalayanEcol.sustain dev. 5, 0973-7502.

[26] Afiukwa, \& Eboatu (2013). Analysis of spring water quality in Ebonyi south zone and its health impact.2153-649X. 